\title{
Successful Management of Russel's Viper Snake Envenomation in a Female Dog
}

\author{
S. Vijayakumar ${ }^{1^{*}}$, S. Sivaseelan ${ }^{2}$ and K. Dhandapani ${ }^{3}$ \\ ${ }^{1}$ Department of Animal Husbandry, Erode, Tamil Nadu, India \\ ${ }^{2}$ University Training Research Centre, Dindigul, Tamil Nadu, India \\ ${ }^{3}$ Department of Veterinary Parasitology, Veterinary College and Research Institute, \\ Thirunelveli, Tamil Nadu, India \\ *Corresponding author
}

\section{A B S T R A C T}

\section{Keywords}

Russell's viper, German shepherd crossbred dog, Snakebite, Blood Clotting time, Treatment

Article Info

Accepted:

04 May 2019

Available Online:

10 June 2019
A six year old female German shepherd crossbred dog was reported with the history of snake bite by Russell's viper, acute onset of oozing of blood from inner side of the oral cavity, oedematous face, congested conjunctival mucus membrane, restlessness and respiratory distress and signs of disseminated intravascular coagulation. Animal was treated with Polyvalent Snake Venom followed by supportive therapy of Tetanus Toxoid, Dexamethasone, Atropine Sulphate, and antibiotic combinations like ceftriaxone and metronidazole along with liver tonic. Whole Blood Clotting time took more than 20 minutes after the administration of first dose, a second dose was administered. Animal made an uneventful recovery after 5 days. Successful therapeutic management of snake envenomation in a German shepherd crossbred dog is presented.

\section{Introduction}

In the Indian subcontinent, out of about 216 species of snakes documented, 52 are considered to be poisonous and the common venomous snakes encountered are Cobra, King Cobra, Russell's viper, Saw Scaled Viper and Krait. Snake bites in domestic animals occur more common in dogs and horses compared to cattle, sheep and goat Garg (2000). The clinical effects are more severe in small animals as compared to large animals. The severity of the bites in animals depends upon the type of snake, age of the animal, size of the animal, number of bites and the amount of venom injected. Snake bite with envenomation is an emergency, which needs rapid examination and proper treatment Vijayakumar et al., (2001) or otherwise delayed and inadequate treatment may lead to untoward consequences. The present paper deals with a case of Russell's viper (Daboia 
russelii) snake bite in a dog and its successful therapeutic management.

\section{Case history and clinical observations}

A 6 years old female German shepherd crossbred dog weighing $16 \mathrm{Kg}$ was presented to the Veterinary Dispensary, A. Puthupalayam, Erode, and Tamil Nadu with the history of Russell's viper snake bite.

Physical examination of the animal revealed oozing of blood from bitten areas (inner side of the oral cavity and left inner lips) (Fig. 1), oedematous face, congested conjunctival mucus membrane, restlessness and respiratory distress. The clinical parameters viz., rectal temperature, respiration and heart rates were recorded following standard clinical examination methods Kelly (1984).

Whole blood was collected and tested for twenty minutes to assess the clotting time. Based on the history and fang-marks on the body, it was diagnosed as Russell viper snake bite and was treated with $10 \mathrm{ml}$ of Polyvalent Snake Venom slowly administered along with the $500 \mathrm{ml}$ of DNS (Dextrose Normal Saline) intravenously followed by supportive therapy of Dexamethasone @ $2 \mathrm{mg} / \mathrm{kg}$ i/v, Atropine Sulphate @ $0.04 \mathrm{mg} / \mathrm{kg} \mathrm{i} / \mathrm{m}$, and Tetanus
Toxoid $0.5 \mathrm{ml} \mathrm{i} / \mathrm{m}$. The antibiotic therapy was continued for three days with Ceftriaxone@ $25 \mathrm{mg} / \mathrm{kg}$ i/v and Metronidazole @ $5 \mathrm{mg} / \mathrm{kg}$ $\mathrm{i} / \mathrm{v}$ along with the liver tonic.

\section{Results and Discussion}

Snake venoms are composite mixture of many enzymes, proteins and peptide compounds. The Rusell's viper venom is majorly haemotoxic but also neurotoxic. According to Segev et al., (2004), venom-induced thrombocytopenia is frequently observed in animals and people with moderate to severe viper envenomation. Possible mechanisms leading to thrombocytopenia in viper envenomation include vasculitis, sequestration of platelets in inflamed tissue, and consumption of platelets with potential development of disseminated intravascular coagulation (DIC). According to Klaassen (2008), hyalurinadase cleaves internal glycoside bonds in certain acid mucopolysaccharides resulting in decreased viscosity of connective tissues allowing other fractions of venom to penetrate the tissues. The cyanotic edema observed at the site of bite may be attributed to enzyme hyaluronidase which acts as a spreading factor.

Fig.1 Oozing of blood from inside the oral cavity and inner lips

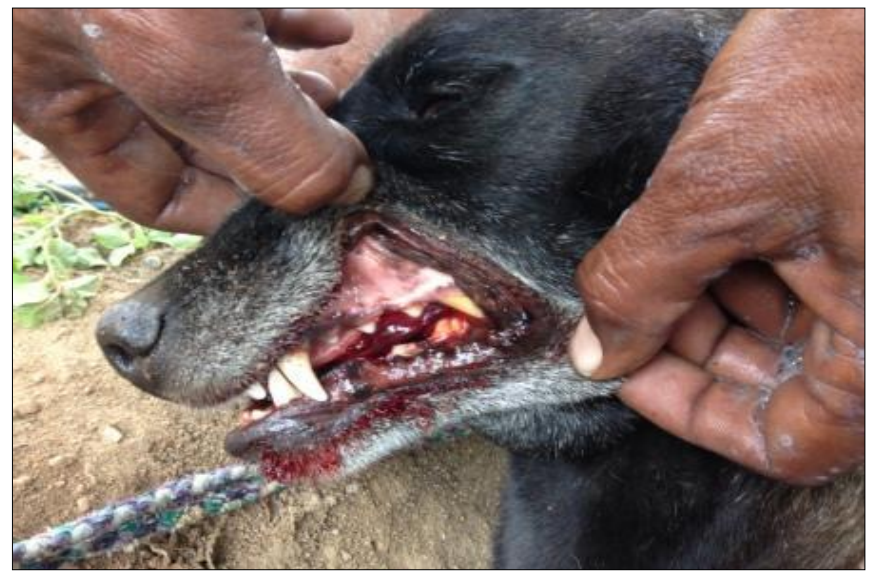


The swelling and necrosis at the site of bite is majorly because of proteolytic enzymes, collagenase, Phospholipase A2, and 5' Nucleotidase etc., Garg (2000). The bleeding from the wound suggested the effect of venom interference in many components of haemostatic system (Wolff, 2006). Sometimes lyophilized polyvalent anti-snake venom may cause anaphylactic reactions Sai et al., (2008) and to overcome this untoward effect to antivenom, dexamethasone injection was given to the dogs. Atropine sulphate is given to prevent the undesirable muscarinic effects of acetylcholine such as increased secretions, bradycardia and colic. Prophylactically, Shukla (2009) suggested that the administration of tetanus toxoid provides protection against the tetanus spore that might have entered animal body from contaminated snake mouth and broad spectrum antibiotic were administered to the dogs, as the fangs of the snake are supposed to be contaminated with various types of bacteria. The treatment of present case with various drugs is in accordance with Singh (2015). Also the twenty minute clotting time of whole blood plays an important role in determining the administration of Polyvalent Snake Venom Antiserum. If failure to clot by 20 minutes indicated that case requires repeated administration of Polyvalent Snake Venom Antiserum. In this present case, since the blood clotting took more than 20 minutes after the administration of first dose, a second dose was administered.

\section{References}

Garg, SK., 2002. In Zootoxins. Veterinary Toxicology, CBS publishers and Distributers 1st Edn New Delhi.

Kelly, W.R., 1984. Veterinary Clinical Diagnosis [Bailliere Trndall, London, 3th edn].

Klaassen, C.D., 2008. Properties and Toxicities of animal Venoms. Toxicology. 7th Edn, McGraw-Hill, New Delhi. Pp. 1093-1098.

Sai, M., Satish, K., and Thirumala, RS. 2008. Therapeutic management of snake bite in a dog. Intas Polivet. 9:116-118.

Segev, G., Shipov, A., Klement, E., Harrus, S., Kass, P. and Aroch, I. (2004).Vipera palaestinae envenomation in 327 dogs: a retrospective cohort study and analysis of risk factors for mortality. Toxicon. 43: 691-99.

Shukla, PC., 2009. Snake bite in animals and its treatment. Pashudhan.; 35(2): 2-4.

Singh, T., 2015. Clinical Management of Snake Bite in a Dog. Intas Polivet. 16(1):138-139.

Vijayakumar, G.,S.G. Kavita, K. Krishnakumar, P.S. Thirunavukkerasu and Subramanian, M. 2001. Snake envenomation in dog- A case report. Indian Vet J.; 78: 1146-1149.

Wolff, F.A.D., 2006. Natural Toxins. In: Clarke's Analysis of Drugs and Poison. Pharmaceutical press, London, Electronic Version.

\section{How to cite this article:}

Vijayakumar, S., S. Sivaseelan and Dhandapani, K. 2019. Successful Management of Russel's Viper Snake Envenomation in a Female Dog. Int.J.Curr.Microbiol.App.Sci. 8(06): 39-41. doi: https://doi.org/10.20546/ijcmas.2019.806.006 